Seyahat ve Otel İşletmeciliği Dergisi/

Journal of Travel and Hospitality Management

14 (1), 2017, 6-19.

Gönderim Tarihi:06.01.2016

Kabul Tarihi: 27.04.2016

\title{
$X, Y$ ve Z Kuşaklarındaki Turistlerin Destinasyon İmaj Algılarının Karşılaştırılması
}

\author{
The Comparison of $\mathrm{X}, \mathrm{Y}$ and $\mathrm{Z}$ Tourists Perceptions of Destination Image
}

\author{
Yrd. Doç. Dr. Gülseren ÖZALTAŞ SERÇEK \\ Mardin Artuklu Üniversitesi \\ Turizm İşletmeciliği ve Otelcilik Y. O. \\ E-posta: g.ozaltas@gmail.com
}

\author{
Arş. Gör. Dr. Sadık SERÇEK \\ Dicle Üniversitesi \\ IỉBF Turizm İşletmeciliği Bölümü \\ E-posta: sadik.sercek@dicle.edu.tr
}

Öz

Turizm pazarından daha fazla pay almak için hem ülkeler hem de turizm destinasyonları büyük bir rekabet içerisine girmişlerdir. Destinasyonlar bir turizm ürünü olarak ve stratejik bir bakış açısıyla ele alınmak zorundadır. Turistler tatillerini geçirecekleri destinasyonları belirlerken birçok faktörden etkilenmektedir. Bu faktörlerden birisi de destinasyon imajıdır. Turistin destinasyon seçiminde seyahat öncesinde imaj oluşumu en önemli aşamadır ve bu nedenle davranışı etkilemeden önce imajın nasıl oluştuğunu anlamak gerekmektedir. Destinasyon imajı bireylerin bir yer hakkındaki genel algılarıdır ve bu algılar yaş, eğitim, gelir, kültür gibi birçok faktörden etkilenmektedir. Sosyo-demografik karakteristikler içinde en çok yaşın imajı etkilediği anlaşılmaktadır. Araştırmanın amaçlarını gerçekleştirmek için literatür taraması sonucunda oluşturulan veri toplama aracı, 2015 yılında, Diyarbakır'da ikamet eden, 16-50 (X, Y ve Z Kuşakları) yaş arasında olan, yılda en az bir kere seyahat eden bireyler Basit Tesadüfi Örnekleme Yöntemi ile uygulanmış ve 600 anket değerlendirmeye tabi tutulmuştur. Elde edilen veriler bilgisayarlı paket programında değerlendirilmiştir. Veriler betimsel istatistik, Tek Yönlü Varyans (ANOVA) ve En Az Anlamlı Fark (LSD) sınaması ile analiz edilmiştir. Araştırmanın sonuçlarına göre destinasyon imajı katılımcıların bulundukları kuşak gruplarına göre farklıık göstermektedir. Kuşak gruplarının özellikle duygusal ve bilişsel algılamalarda etkili olduğu sonucuna ulaşıımıştır.

Anahtar Kelimeler: Destinasyon imajı, X, Y ve Z kuşağı, Turizm.

\begin{abstract}
To get a bigger share of the tourism market, both countries and tourism destination have entered into a major competitive. Destinations as a tourism product and have to be dealt with from a strategic perspective. Tourists are affected by many factors in determining the destinations they spend their holidays. One of these factors is the image of the destination. Image formation prior to traveling to the tourist destination of choice is the most important stage and therefore before influence the behavior must also understand that image of what occurred. Destination image is general perceptions about the place of the individuals and these perceptions are influenced by many factors such as age, education, income, culture. That most affect the image of age within socio-demographic characteristics are understood. Created survey as a result of the literature to realize the objectives of the study, in 2015, residing in Diyarbakır, between 16-50 (X, Y and Z generation) aged who travelled at least once a year applied traveling at least once a year, applied with Simple Random Sampling Method and 600 surveys were subjected to evaluation. The obtained data were analyzed with computerized software. As a method of analysis; In addition to descriptive statistics, one-way analysis of variance (ANOVA) and Least Significant Difference (LSD) test, analysis was performed. According to the survey, vary destination image perceptions vary according to their generation group of participants. Generation has concluded that especially emotional and cognitive perception to be effective.
\end{abstract}

Keywords: Destination image, $\mathrm{X}, \mathrm{Y}$ ve $\mathrm{Z}$ generation, Tourism. 


\section{Giriş}

Turistlerin tatillerini geçirecekleri destinasyon tercihlerinin ve memnuniyet düzeylerinin belirlenmesinde en önemli unsurlardan biri destinasyon imajıdır. Turizm ürünleri soyut ve birbirine benzer oldukları için destinasyonlar arasında rekabet, "imaj" aracılığı ile gerçekleştirilmektedir. Günümüzde hala imajın; karmaşık yapısı, algılamalar sonucunda bireylerin zihninde oluşması, kişiden kişiye ve aynı kişide zaman içerisinde değişiklik göstermesi gibi nedenlerden dolayı tanımlanması, kavramlaştırıması ve ölçülmesi üzerinde bir anlaşmaya varılamamıştır.

İmaj, psikolojide zihinde oluşan bir görsel canlanma olarak, davranış bilimlerinde ise izlenimler, bilgiler, duygular, değerler ve inançları da kapsayan bütünsel bir kavram olarak ele alınmaktadır (Jenkins, 1999: 4). Literatür incelendiğinde, farklı biçimlerde tanımlanmış olan, destinasyon imajını kısaca "bireylerin bir destinasyon hakkında zihinlerinde oluşan algılamaları" şeklinde ifade etmek mümkündür.

Araştırmacılar turistleri farklı özelliklerine göre bölümlere ayırarak her bir bölümün özelliklerini, beklenti, istek ve intiyaçları ile satın alma davranışlarını inceleyerek bölümlemeye uygun hizmet sunabilmek için destinasyon pazarlamasına ilişkin tutundurma faaliyetlerini gerçekleştirmektedir. Turizm pazarı içerisinde yer alan turistlere ilişkin pazar bölümlerinin oluşturulmasında kullanılan yöntemlerden biri de pazarı kuşaklarına göre bölümlemedir. Çünkü her kuşağın kendine has farklı istek ve intiyaçları olduğu, bunun da satın alma davranışlarını etkilediği düşünüldüğünde, böyle bir bölümlendirmenin pazarlama alanında önemli avantajlar sağlayacağı söylenebilir. Bu açıdan bakıldığında, turistlerin beklenti ve memnuniyetlerini belirleyen destinasyon imajı ile ilgili olarak hem günümüzün hem geleceğin turisti olan ve hem de gelecekte turizm davranışı içerisinde yer alacak olan bir sonraki kuşağını oluşturan turistlerin destinasyon imajına ilişkin algılarını ve özelliklerini belirlemenin hem günümüz destinasyon pazarlamacıları için hem de gelecekte destinasyon pazarlaması konusunda çalışacak olanlara yön gösterebileceği düşünülmüştür.

$\mathrm{Bu}$ çalışma, birbirinden farklı özellikler gösteren $X, Y$ ve $Z$ kuşaklarındaki turistlerin tatil yerlerine karar vermeleri üzerine destinasyon imajını oluşturan faktörlerin etkisini saptamak; X, Y ve Z kuşaklarındaki turistlerin yapısal özellikleri ile destinasyon imajı algılarının karşılaştırarak söz konusu kuşaklar için destinasyon imajına etki eden faktörlerin belirlenerek turizm pazarlamasına ilişkin önerilerde bulunmak amacıyla yapılmıştır. Literatürde, turistlerin destinasyon tercihleri ile ilgili çeşitli çalışmalar yapılmış ve bu çalışmalarda genel olarak turistlerin yaş, eğitim, kültür, gelir gibi özelliklerinin destinasyon imaj algıları üzerine etkileri incelenmiştir ancak farklı kuşaklardaki bireylerin destinasyon imaj algılarının karşılaştırılmasına yönelik ile ilgili herhangi bir çalışmaya rastlanmamıştır. Bu nedenle bu çalışma sonucunda elde edilen sonuçların gerek literatüre gerekse turizm pazarlamacılarına katkı sağlayabileceği düşünülmüştür.

\section{Literatür Taraması}

Akademisyenlerin ve turizm pazarlamacılarının destinasyon imajı kavramının önemi üzerinde durmaya, turistlerin seyahat kararları üzerindeki etkisinin araştırmaya, turistik destinasyonların marka olarak ele alınmaya başlanması, beraberinde destinasyon imajı kavramının tanımlaması ve imajının kavramlaştırılması için çalışmaların da yapılmasına neden olmuştur.

İmaj, bir ürünün, bir kişinin, bir yerin, bir şeyin nasıl bilindiği; ürünü çok satmak amacıyla yapılan her türlü faaliyet ya da ürünün müşteri tarafından algılanan resmi 
olarak farklı şekillerde tanımlanabilmektedir. Destinasyonların ve turizm işletmelerinin sahip oldukları imajlar turizm ürünü olarak ele alındığı gibi, turizm ürünü veya destinasyonun imajının da, tüketicinin nihai seçimi üzerinde etkili olduğu kabul edilmektedir (Kozak ve Bahçe, 2009: 71).

Destinasyon imajının akademisyenlerce ortak bir tanımının yapılmamasına rağmen, akademisyenler imaj kavramının destinasyon pazarlamasında, turizm destinasyonlarının kalkınmasında ve pazarlama stratejilerinin geliştirilmesinde vazgeçilmez bir unsur olduğunu ortaya koymuşlardır (Aksoy ve Kiyci, 2011: 481). Destinasyon imajı temelde bir psikolojik kavram olarak bireylerin bir yer veya ürün hakkında zihinlerinde ortaya çıkan bir resimdir (Gibson, Qi ve Zhang, 2008: 433). Her kişi yasamış olduğu olaylardan, duymuş veya toplamış olduğu bilgilerden aynı derecede ve aynı şekilde etkilenmeyeceğinden, zihinlerinde değişik şekillerde intibalar oluşacaktır. Oluşan bu intibalar, kişilerin zihninde o yer hakkındaki soyut düşünceler olarak farklı şekilde kavramlaşacaktır.

Ryan (2003) ise herhangi bir destinasyonun imajının özelliklerini: dinamiktir çünkü değişebilir, görecelidir çünkü içerisinde karşılaştırmaları içerir, çok yönlüdür çünkü farklı özelliği ve özelliklerin değerlendirilmesini kapsar ve genelleştirilmesi çok zordur şeklinde açıklamaktadır. Yapılan bütün tanımlamaların ortak noktası insan zihnidir. Destinasyon imajının bireyin zihninde canlanması ve ortaya çıkması, bütün ziyaretçiler için bir imajın önceden tasarlanmasını mümkün kılamamaktadır (Sarma, 2007: 39).

Turizm alanında birçok araştırmacı, destinasyon imajı kavramını sık sık kullansa da bu kavramı kesin bir tanıma oturtmaktan kaçınır (Echtner ve Ritchie, 2003: 41). Destinasyon imajının özelliklerini yazarlar farklı şekillerde açıklamaya çalışmaktadır. Ancak temelde düşünüldüğünde, destinasyon imajı sadece kişiden kişiye değişmekle kalmayıp, aynı kişinin bir yer hakkında sahip olduğu imaj da zaman içerisinde değişiklik gösterebilmektedir. Bu nedenle sübjektif, değişebilen ve genelleme yapılması çok zor olan destinasyon imajının her ne kadar ölçümü çok zor olsa bile, belirli zaman aralıkları ile ölçülmesi, bir destinasyonun turistik destinasyon olarak daha başarılı olması veya başarısının devamı için zorunludur.

İmaj turistik tanıtım açısından son derece önemlidir. Olumlu bir turistik imaja sahip olunması uluslararası turizm hareketliliklerini biçimlendiren önemli bir etkendir (Şahbaz ve Kılıçlar, 2009: 4). Destinasyonların ve turizm işletmelerinin sahip olduğu imajları da turizm ürününü oluşturan unsurlar içerisine dahil olmaktadır. Çünkü turistlerin herhangi bir turizm ürününü tercih etmelerindeki en önemli nedenlerde birisi, o ürünü sahip olduğu imajdır. Turistik ürünlerin imajlarının, turistlerce yüksek olması söz konusu ürüne olan talebi önemli derecede etkileyecektir. Day, Skidmore ve Koller (2002) destinasyon imajının etkili olabilmesi için beş temel özelliğe sahip olması gerekliliği üzerinde dururken bu özellikleri; geçerli, inandırıcı, basit, çekici ve ayırt edici olarak açıklamaktadır.

Baloğlu ve McCleary (1999: 870) tarafından geliştirilen modelde uyarıcı ve kişisel faktörler olarak adlandırdıkları faktörlerin destinasyon imajını etkilediklerini ve imajın bu etkileşim sonucunda oluştuğunu belirtmektedirler. 
Şekil 1: Destinasyon İmaj Oluşumuna Etki Eden Faktörler

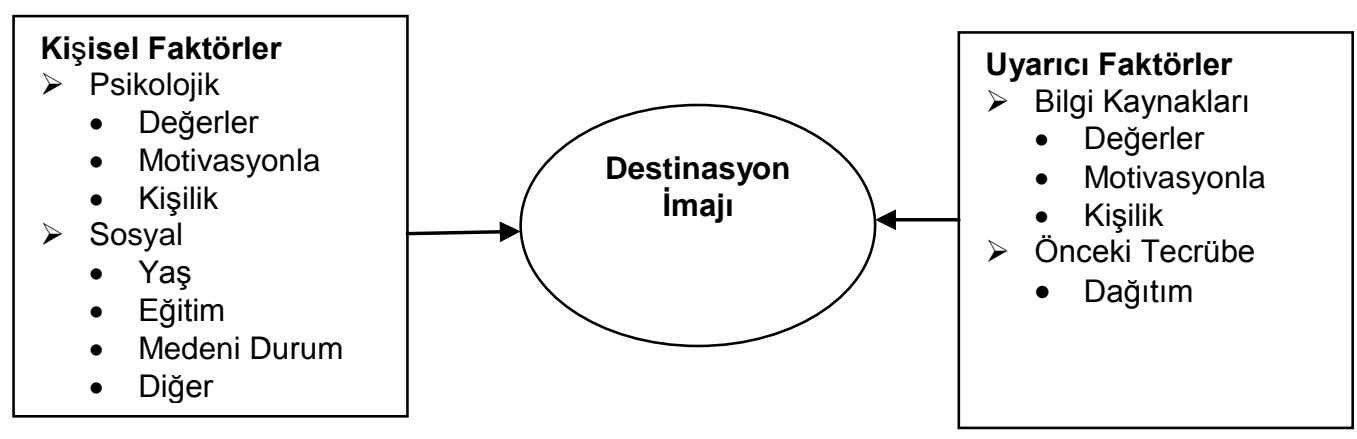

Kaynak: Baloğlu ve McCleary, 1999: 870

Destinasyon İmajı ilişkin olarak geliştirilen bir diğer model de Beerli ve Martin (2004: 660) modelidir. Söz konusu model bir destinasyon hakkında sahip olunan pozitif veya negatif olan genel imajın birbirine çok yakın ve ilişkili iki kavram olan bilişsel/algısal ve duyuşsal imaj unsurlarından oluştuğunu belirtmektedir.

Şekil 2: Destinasyon İmaj Oluşumuna Etki Eden Faktörler

\begin{tabular}{|l|l|}
\hline BíLGi KAYNAKLARI \\
$>$ & İkincil \\
& - Uyarıcı \\
& - Organik \\
& - Bağımsız \\
$>$ & Birincil \\
& - Önceki deneyim \\
& - Seyahat yoğunluğu \\
\hline
\end{tabular}

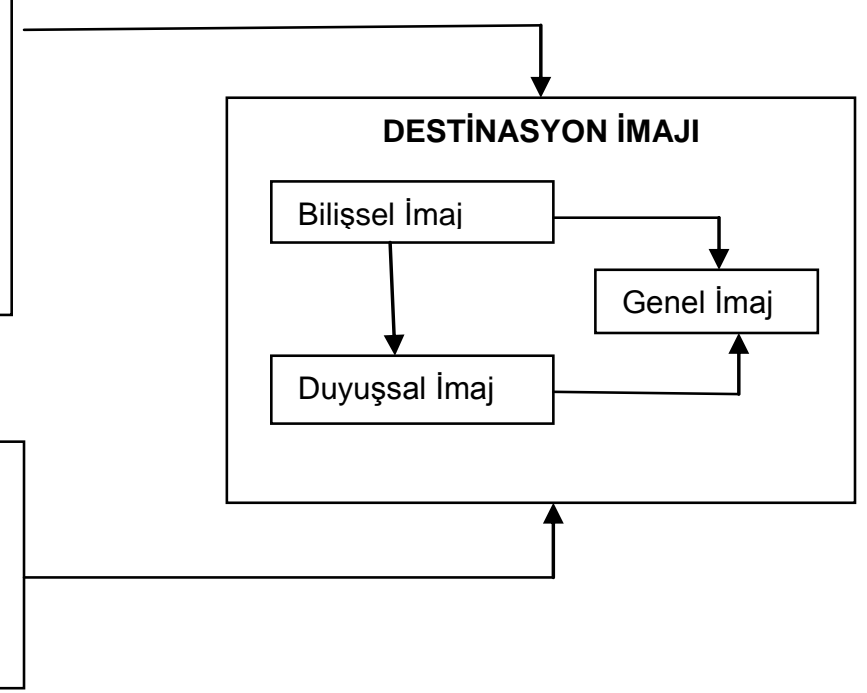

Kaynak: Beerli ve Martin, 2004: 660.

Destinasyon imajı ile ilgili çalışmaların yapılmaya başlandığı ilk dönemlerde, imaj oluşumuna etki eden faktörlerin ifade edilmesinde iki farklı görüş bulunmaktaydı. Birinci görüş imaj farklılaşmasını sadece bireysel farklılıklara dayandırırken, ikinci görüş ise imajın destinasyon kaynaklı olduğunu ve uyarıcı faktörlerin etkisi ile oluştuğunu ve farklılaştığını savunmaktaydı. Bu iki görüş arasındaki farklııık zaman içerisinde ortadan kalkarak imaj oluşumuna etki eden faktörlerin hem bireyden hem de destinasyondan kaynaklandığı konusunda fikir birliğine varılmıştır (Baloğlu, 1996).

Turistlerin bir yeri tercih etmesindeki en önemli etkenlerden birisi o destinasyonun imajıdır. İmaj ve deneyimlerden oluşan beklentiler, turist açısından birbiriyle yakından bağlantılı elemanlar olup, turistik ürünün soyut yanını oluşturmaktadır. Turistik çekiciliğe sahip destinasyon imajının oluşumu uzun süre 
almakta ve oluştuktan sonra imajının değişikliğe uğraması veya imajda bir azalma olması oldukça güç olmaktadır. Bir destinasyonun imajının olumlu oluşumunu sağlayan değerler, kalıtlar ve doğal güzellikler değişse veya ortadan kalksa bile imaj varlığını uzun süre koruyabilmektedir. Sadece imajını yeni oluşturmuş destinasyonların değil, eski dönemlerde imaj oluşturmuş destinasyonların da çekim gücü vardır (Jafarov. 2003: 36).

Bireysel faktörler kapsamında ele alınan ve önemli bir etken olan yaş ve yaşam dönemlerinden kaynaklı satın alma alışkanlıklarında farklılıklar gözlemlenmektedir. Özellikle bireylerin tatil anlayışlarında, seyahat yeri tercihlerinde, yeme içme alışkanlıklarında ve eğlence anlayışlarında meydana gelen değişiklikler ile yaşları arasında bir ilişki bulunmaktadır (Kotler, Bowen ve Makens, 1999). Her kuşağın kendine özgü özellikleri, değer yargıları, tutumları, güçlü ve zayıf yönleri bulunmaktadır (Lower, 2008: 81). Geçmişten bu güne kuşaklar beş grup altında toplanmaktadır. Bunlar; Gelenekselciler (1930-1945), Bebek Patlaması (1946-1964), X Kuşağı (19651976), Y Kuşağı (1977-1994) ve Z Kuşağıdır (1994 ve sonrası) (Williams ve Page, 2011: 2-8). Her kuşak grubunun kendine özgü farklı özellikleri, beklentileri, yaşantıları ve koşulları bulunmaktadır. Yaşam dönemleri ve turizm işletmeleri yaklaşımları arasındaki ilişki aşağıdaki Tablo 1'de de açık olarak görülebilmektedir.

Tablo 1: Tüketici Kuşakları, Yaşam Dönemleri ve Turizm Endüstrisi Yaklaşımı

\begin{tabular}{|c|c|c|c|}
\hline Kuşak & Yaş Dönemi & Yaş & $\begin{array}{c}\text { Turizm Endüstrisi Tüketici } \\
\text { Yaklaşımı }\end{array}$ \\
\hline \multirow{5}{*}{ Z Kuşağı } & $\begin{array}{l}\text { Erken } \\
\text { Çocukluk }\end{array}$ & $0-5$ & $\begin{array}{l}\text { Aileler için sorunlu tüketiciler, oyuncak, çocuk } \\
\text { pansiyonları, bazı restoranlarda çocuk bakıcıları }\end{array}$ \\
\hline & $\begin{array}{l}\text { Genç } \\
\text { Çocukluk }\end{array}$ & $6-12$ & $\begin{array}{l}\text { Dışarıda yemek konusunda önemli etkileri var. } \\
\text { Resort otellerde çocuklu için özel rekreasyon } \\
\text { programları }\end{array}$ \\
\hline & İlk Gençlik & $13-15$ & $\begin{array}{l}\text { Bağımsız tüketici olmaya başlar. Dışarıda yemek } \\
\text { yemeği halen etkilerler }\end{array}$ \\
\hline & İleri Gençlik & $16-19$ & $\begin{array}{l}\text { Bağımsız tüketici, bazen yarı zamanlı islerde } \\
\text { çalışılar. Sosyal etkinlik gereksinimleri oldukça } \\
\text { fazladır. }\end{array}$ \\
\hline & Genç Bekarlar & $20-24$ & $\begin{array}{l}\text { İşyaşamına atılırlar. Düşük bütçe ile seyahate } \\
\text { çıkarlar }\end{array}$ \\
\hline Y Kuşağı & Genç Evliler & $25-38$ & İki gelirlidirler. Seyahate fazla eğilimleri vardır. \\
\hline X Kuşağı & Genç Orta Yaş & $39-50$ & $\begin{array}{l}\text { Gelirleri yüksektir. Çocuklarının giderleri vardır. } \\
\text { Dışarıda yemek yeme ve seyahat eğilimleri fazladır. }\end{array}$ \\
\hline $\begin{array}{c}\text { Bebek } \\
\text { Patlaması }\end{array}$ & İleri Orta Yaş & $50-65$ & $\begin{array}{l}\text { Gelirleri en yüksek düzeydedir. Seyahate fazla } \\
\text { eğilimleri vardır. Dışarıda az yemek isterler }\end{array}$ \\
\hline \multirow{3}{*}{ Gelenekselciler } & Genç Yaşlı & $65-75$ & $\begin{array}{l}\text { Yeterli ve sabit gelirler vardır. Boş zamanları çok } \\
\text { fazladır. Diyet yemeklerine dikkat ederler. Gezmeyi } \\
\text { severler }\end{array}$ \\
\hline & Yaşlı & $75-84$ & $\begin{array}{l}\text { Sağlık sorunları vardır. Genelde dul ya da } \\
\text { yalnızlardır. }\end{array}$ \\
\hline & Çok Yaşlı & $85+$ & $\begin{array}{l}\text { Kuzey Amerika'da sayıları hızla artmaktadır. \%70’i } \\
\text { kadındır, özel diyet yemekleri isterler. }\end{array}$ \\
\hline
\end{tabular}

Kaynak: Williams ve Page, 2011: 2-8; içöz, 2001: 79.

Geleneksel olarak kuşak, ebeveynlerin ve çocuklarının doğumları arasındaki ortalama zaman aralığını ifade etmektedir. Türk Dil Kurumu Felsefe Terimleri Sözlüğü, kuşak kavramını aşağı yukarı aynı yıllarda doğmuş olup aynı çağın koşullarını, dolayısıyla birbirine benzer sıkıntıları, yazgıları yaşamış, benzer ödevlerle yükümlü olmuş kişiler topluluğu olarak tanımlamaktadır (http://www.tdkterim.gov.tr). 
Artan rekabet tüketici davranışlarını incelemek üzere özel araştırmalar yapılmasını zorunlu kılmaktadır (Kotler ve Armstrong, 2004). İnsanlar farklı istekleri, alışkanlıkları, deneyimleri sonucu farklı satın alma davranışları sergilemektedirler. Her kuşak, kendi kuşağının beğenilerini dikkate almakta, moda olarak kabul edilen eğilimlerden etkilenmektedir. Bu nedenle pazarlama teorisyenleri hedef müşterilerini belirlemek ve onlara daha iyi yollardan ulaşabilmek için geniş olan pazarı daha küçük bölümlere ayırma yoluna gitmişlerdir. Bu bölümlemelerden biri de insanları yaşlarına göre kuşaklara ayırma yöntemidir (Can, 2012).

Turistin destinasyon seçiminde seyahat öncesinde imaj oluşumu en önemli aşamadır ve bu nedenle davranışı etkilemeden önce imajın nasıl oluştuğunu anlamak gerekmektedir. Sosyo-demografik karakteristikler içinde en çok yaş ve eğitim düzeyinin imajı etkilediği anlaşılmıştır. Örneğin; ABD’ye giden Alman turistler üzerine yapılan bir araştırmada algılanan imajı farklılaştıran en önemli faktör olarak yaş ortaya çıkmıştır (Baloğlu, 1997).

\section{Araştırmanın Yöntemi}

\subsection{Araştırma Modeli}

Bu çalışma, " $X, Y$ ve $Z$ Kuşaklarındaki Turistlerin Destinasyon İmaj Algılarını" değerlendirmeye yönelik genel tarama türünde betimsel bir çalışmadır. Betimleme, olayları obje ve problemleri anlama ve anlatmada ilk aşamayı oluşturur. Bilimsel etkinlikler olayların betimlenmesiyle başlar. Bu sayede onları iyi anlayabilme, gruplayabilme olanağı sağlanır ve aralarındaki ilişkiler saptanmış olur (Kaptan, 1998: 59). Betimsel tarama modelinde bilimin gözleme, kaydetme, olaylar arasındaki ilişkileri tespit etme ve kontrol edilen değişmez ilkeler üzerinde genellemelere ulaşma söz konusudur (Yıldırım ve Şimşek, 2005: 75).

\subsection{Evren ve Örneklem}

Evren kuşak değişkenine göre sınırlandırıldığından kota örnekleme yöntemi kullanılmıştır. Araştırmanın hedef kitlesini, Diyarbakır'da ikamet eden, 16-50 (X, Y ve Z Kuşakları) yaş arasında olan, yılda en az bir kere seyahat eden bireyler Basit Tesadüfi Örnekleme Yöntemi ile seçilmiştir. Özdamar (2001: 257) tarafından $d=+-0,05$ örnekleme hatası ve $p=0,05, q=0,05$ güven aralığında evrenin 10.000 den fazla olması durumunda örneklem büyüklüğünün 384 olması gerektiğinin belirtilmiş olduğu Örneklem Büyüklüğü Tablosundan yararlanıımıştır. Araştırmada belirlenen eşik (sınır) değeri olan 384 sayısının üzerine çıkılarak 600 kişiye ulaşılmıştır.

\subsection{Veri Toplama Aracı}

Çalışmada bilimsel araştırmalarda başvurulan ana metotlardan iki tanesine yer verilmektedir. Birincisi, temel araştırma tekniğidir. Burada; çalışmanın teorik yapısını oluşturmak için konu ile ilgili gerek yurt içi gerekse yurt dışında yayınlanan bilimsel çalışmalardan yararlanılmıştır. İkinci yöntem ise, teorisi oluşturulan çalışma ile ilgili alan araştırması yapılmasıdır. Bu araştırmada, Baloğlu ve McCleary (1999: 871) tarafından geliştirilen destinasyon imajı oluşum modelinden yararlanılarak veri toplama aracı hazırlanmıştır. Veri toplama aracı Diyarbakır'da faaliyet gösteren 30 seyahat acentesi ile seyahat eden kişilerle 2015 yılının Eylül, Ekim ve Kasım döneminde yüz yüze görüşerek uygulanmıştır. 
Verilerin faktör analizine uygunluğu Kaiser-Meyer-Olkin (KMO) örneklem yeterliliği ölçütü ve Bartlett Küresellik Testi ile incelenmiştir. İlk aşamada veri toplama aracınca yer alan değişkenlerin tümüne faktör analizi uygulanmış, ancak anlamlı bir faktör yapısına ulaşılamamıştır. Daha sonra değişkenler ayrı ayrı faktör analizine tabi tutulmuştur. Ölçeklerin faktör yüklerinin alt kesme noktası olarak 0.50 alınmıştır. Buna göre, Destinasyon İmajını Etkileyen Faktörlere İlişkin maddelerin KMO değeri 0,92 bulunmuştur. Bu durum verilerin faktör analizi için uygun olduğunu göstermektedir (Leech, Barrett ve Morgan, 2005). Verilerin çok değişkenli normal dağılımdan geldiği ise Barlett Sphericity Testi ile test edilmektedir (Tavşancıl, 2002). Barlett Sphericity testi sonucu; Destinasyon İmajını Etkileyen Faktörlere İlişkin maddelerin X2 değeri $4677,002(p<0.000)$ bulunmuştur. Sonucun anlamlı çıkması, verilerin normal dağılıma sahip olduğunu göstermektedir (Büyüköztürk, 2012). Böylece KMO ve Barlett Testi sonuçları, bu veriler üzerinden faktör analizi yapılabileceğini, yani verilerin faktör analizi için uygun olduğunu ortaya çıkarmıştır.

Tablo 2: X, Y ve Z Kuşağı Turistlere Uygulanan Veri Toplama Aracının Faktör Sonuçları

\begin{tabular}{|l|c|}
\hline Destinasyon Imajını Etkileyen Faktörlere İlişkin Maddeler & Faktörler \\
\hline Hava Koşulları & 0,791 \\
\hline Sahilleri ve Özellikleri & 0,764 \\
\hline Manzara Zenginliği & 0,757 \\
\hline Flora ve Faunanın Benzersiz ve Çeşitli Oluşu & 0,757 \\
\hline Özel ve Kamu Ulaşım Olanaklarının Varlığı & 0,755 \\
\hline Telekomünikasyon Hizmetlerinin Gelişmişliği & 0,718 \\
\hline Ticari Alt Yapının Varı̆ı̆ı & 0,714 \\
\hline Inşaat Gelişim Boyutu & 0,704 \\
\hline Konaklama Hizmetlerinin Nitelik ve Kalitesi & 0,773 \\
\hline Restoran Hizmetlerinin Nitelik ve Kalitesi & 0,760 \\
\hline Bar, Disko ve Kulüplerin Varlığı & 0,746 \\
\hline Ulaşımın Kolay Olması & 0,734 \\
\hline Turistik Turların Varlığı & 0,706 \\
\hline Turistik Bilgi Ağının Olması & 0,702 \\
\hline Temalı Parkların OIması & 0,686 \\
\hline Spor İmkanlarının Varlığı & 0,644 \\
\hline Kültür, Sanat ve Tarihe ilişkin Kaynakların Varlığı & 0,639 \\
\hline Sağlık Hizmetlerinin Gelişmişliği & 0,632 \\
\hline Ekonomik Gelişmişlik & 0,621 \\
\hline Güvenli Oluşu & 0,612 \\
\hline Ürün/hizmet Fiyatları & 0,608 \\
\hline Çevrenin Temizliği & 0,601 \\
\hline Aşırı Kalabalıılaşma & 0,585 \\
\hline Hava ve Gürültü Kirliliği & 0,543 \\
\hline Trafik Durumu & 0,511 \\
\hline Yerel Halkın Davranışları & 0,829 \\
\hline Lüks Bir Destinasyon Olması & 0,817 \\
\hline Destinasyona Seyahatin Moda Olması & 0,771 \\
\hline Toplam Varyans & 57,148 \\
\hline
\end{tabular}

Ekstraksiyon Metodu: Temel Bileşenler Analizi

Veri Toplama Aracı güvenirliğini test etmek amacıyla diğer bir deyişle anketin iç tutarlıığını anlayabilmek için güvenirlik hesaplaması yapılmıştır. Güvenirlik, aynı şeyin bağımsız ölçümleri arasındaki kararlılığı, aynı süreçlerin izlenmesi ve aynı ölçütlerin kullanılması ile aynı sonuçların alınması yani ölçmenin tesadüfi hatalardan arınık olması (Karasar, 2009: 148); ölçme aracını oluşturan ifadelerin birbirleriyle tutarlı olup 
olmadığı aralarındaki ilişkinin ölçülmesiyle belirlenir. Güvenirlik katsayısı, 0 ile 1 arasında değer alır ve değer 1'e yaklaştıkça güvenirliğin arttığını gösterir (Ural ve Kılıç, 2006: 286).

Güvenilirlik analizinde, her bir değişkenin alfa katsayılarına bakılmıştır. Buna göre, aşağıda verilen Tablo 3'te ilgili değişkenler ve Cronbach Alfa Katsayıları görülmektedir.

Tablo 3: Veri Toplama Aracının Güvenirlik Katsayısı

\begin{tabular}{|c|c|c|}
\hline Değişken & $\begin{array}{c}\text { Soru } \\
\text { Sayısı }\end{array}$ & $\begin{array}{c}\text { Cronbach Alfa } \\
\text { Katsayıları }\end{array}$ \\
\hline Destinasyon İmajını Etkileyen Faktörler & 28 & 0,916 \\
\hline
\end{tabular}

Veri toplama aracında yer alan boyutun Cronbach Alpha katsayısı 0,916 bulunmuştur. Bu sonuçlar araştırmada kullanılan veri toplama aracının yüksek derecede güvenilir olabileceğini göstermektedir.

\subsection{Verilerin Analizi}

Çalışmadan elde edilen verilerin analizi SPSS (Statistical Package for the Social Science) ve AMOS (Analysis of Moment Structures) paket programları ile yapılmıştır. SPSS ile analiz edilecek verilerde kullanılacak istatistiksel yöntemleri belirlemek amacıyla normal dağılıma uygunluk analizinde Kolmogrov-Smimov $Z$ testi kullanılmıştır. Gözlem sayısının 30'un altında olduğu durumlarda Shapiro-Wilk, 30 ve üzerinde olduğunda da Kolmogrov-Smimov Z testi önerilmektedir (Can, 2013: 89).

Ayrıca verilerin homojenlik testi için Levene's testi kullanılmıştır. Bu testlerin sonuçlarına göre, parametrik dağılım varsayımlarını yerine getiren verilerin çözümlenmesinde parametrik testler kullanılırken söz konusu varsayımları yerine getirmeyen veriler için de non-parametrik testler kullanılmıştır.

\section{Bulgular ve Tartışma}

Araştırmaya katılan erkek sayısının kadın sayısından fazla olduğu, lise mezunlarının ilk sırada yer aldığı ve yarıdan fazlasının (\%56) ayda 3000 TL üzeri gelire sahip olduğu anlaşılmaktadır.

Tablo 4: Katılımcıların Demografik Özelliklerine Göre Dağılımı

\begin{tabular}{|c|c|c|c|c|c|c|}
\hline \multicolumn{2}{|c|}{ DEĞIŞKENLER } & Z Kuşağı & Y Kuşağı & X Kuşağı & f & $\%$ \\
\hline \multirow{3}{*}{ Cinsiyet } & Erkek & 102 & 104 & 111 & 317 & 55 \\
\hline & Kadın & 98 & 96 & 89 & 283 & 45 \\
\hline & Toplam & 200 & 200 & 200 & 600 & 100 \\
\hline \multirow{5}{*}{$\begin{array}{l}\text { Öğrenim } \\
\text { Durumu }\end{array}$} & İlköğretim & 37 & 15 & 43 & 95 & 16 \\
\hline & Lise & 70 & 116 & 62 & 248 & 41 \\
\hline & Üniversite & 50 & 50 & 52 & 152 & 25 \\
\hline & Lisansüstü & 43 & 19 & 43 & 105 & 18 \\
\hline & Toplam & 200 & 200 & 200 & 600 & 100 \\
\hline \multirow{6}{*}{ Gelir (TL) } & $<1.000$ & 32 & 5 & 36 & 73 & 12 \\
\hline & $1.001-2.000$ & 37 & 15 & 35 & 87 & 14 \\
\hline & $2.001-3.000$ & 38 & 30 & 38 & 106 & 18 \\
\hline & $3.001-4.000$ & 41 & 38 & 32 & 111 & 19 \\
\hline & $>4.001$ & 52 & 112 & 59 & 223 & 37 \\
\hline & Toplam & 200 & 200 & 200 & 600 & 100 \\
\hline
\end{tabular}


Z kuşağı katılımcıların tatile çıkma davranışına ilişkin verilere Tablo 5 'te yer verilmiştir. Buna göre $Z$ kuşağı katılımcılar tatile çıkma sıklıkları açısından incelendiğinde katılımcıların yarına yakını (\% 42) yılda bir kez tatile çıkarken bunu yılda iki kez tatile çıkanlar (\% 37) ve yılda üç kez ve daha fazla tatile çıkanlar (\% 21) takip etmektedir. Katılımcılar en fazla eğlence (\% 32) nedeniyle tatile çıkarken bunu birbirlerine çok yakın oranlarla tarihi ve doğal yerleri görme (\% 16), yeni yerler görme (\% 13), dinlenme (\% 13), rahatlama (\% 13) ve tanıdıkları görme nedenleri (\% 13) takip etmektedir. Z kuşağı katılımcıların tatil yeri seçiminde etkili olan üç faktör incelendiğinde katılımcılar tatil yeri seçiminde etkili olan en önemli üç faktör olarak eğlence (\% 25), spor olanakları $(\% 18)$ ve tarihi ve kültürel çekicilikler (\%16.5) olduğunu belirtirlerken tatil yerine karar vermelerinde en fazla yararlandıkları üç bilgi kaynağı olarak internet (\% 76), tanıdık tavsiyeleri (\% 8) ve seyahat acentelerinden (\% 5) yararlandıklarını belirtmişlerdir.

Tablo 5: Katılımcıların Tatile Çıkma Davranışlarına İlişkin Dağılımı

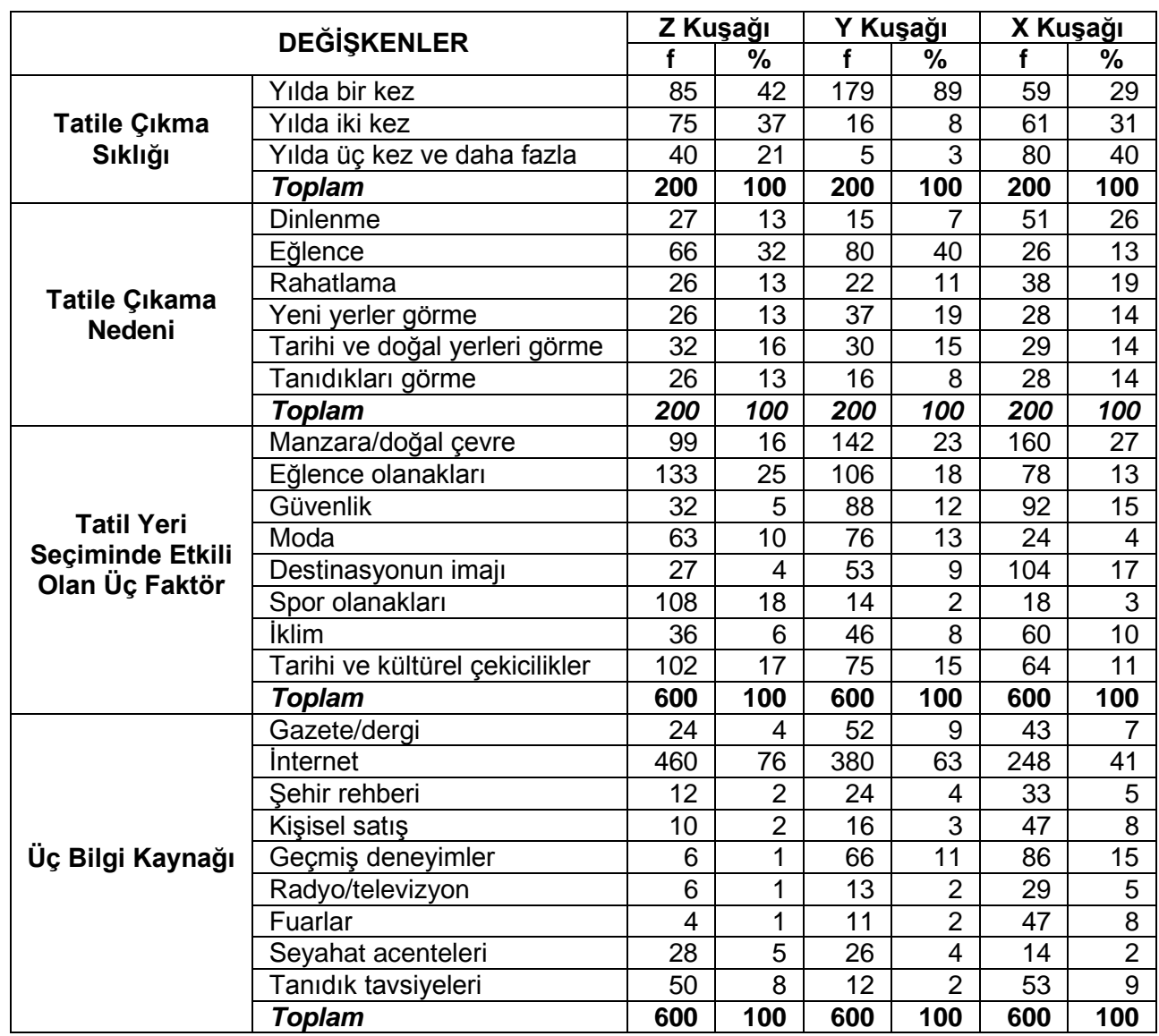

Y kuşağı katılımcıların tatile çıkma davranışına ilişkin verilere Tablo 5'te yer verilmiştir. Buna göre $Y$ kuşağı katılımcılar tatile çıkma sıklıkları açısından incelendiğinde katılımcıların yarısından fazlası (\% 89) yılda bir kez tatile çıkarken bunu yılda iki kez tatile çıkanlar (\% 8) ve yılda üç kez ve daha fazla tatile çıkanlar (\% 3) takip etmektedir. Katılımcılar en fazla eğlence (\% 40) nedeniyle tatile çıkarken bunu sırasıyla yeni yerler görme (\% 19), tarihi ve doğal yerleri görme (\% 15), rahatlama (\% 11), tanıdıkları görme (\% 8) ve dinlenme nedenleri (\% 7) takip etmektedir. Y kuşağı katılımcıların tatil yeri seçiminde etkili olan üç faktör incelendiğinde katılımcılar tatil yeri 
seçiminde etkili olan en önemli üç faktör olarak manzara/doğal çevre (\% 23), eğlence olanakları (\% 18) ve tarihi ve kültürel çekicilikler (\% 15) olduğunu belirtirlerken tatil yerine karar vermelerinde en fazla yararlandıkları üç bilgi kaynağı olarak internet (\% 63), geçmiş deneyimler (\% 11) ve gazete/dergi (\% 9) yararlandıklarını belirtmişlerdir.

X kuşağı katılımcıların tatile çıkma davranışına ilişkin verilere Tablo 5'te yer verilmiştir. Buna göre $X$ kuşağı katılımcılar tatile çıkma sıklıkları açısından incelendiğinde katılımcıların yarısına yakını (\% 40) yılda üç kez ve daha fazla tatile çıkarken bunu yılda iki kez tatile çıkanlar (\% 31) ve yılda bir kez tatile çıkanlar (\% 29) takip etmektedir. Katılımcılar en fazla dinlenme (\% 26) ve rahatlama (\% 19) nedeniyle tatile çıkarken bunu birbirlerine çok yakın oranlarla tarihi ve doğal yerleri görme (\% 14), yeni yerler görme (\% 14), tanıdıkları görme (\% 14) ve eğlence nedenleri (\% 14) takip etmektedir. X kuşağı katılımcıların tatil yeri seçiminde etkili olan üç faktör incelendiğinde katılımcılar tatil yeri seçiminde etkili olan en önemli üç faktör olarak manzara/doğal çevre (\% 27), destinasyonun imajı (\% 17) ve güvenlik (\% 15) olduğunu belirtirlerken tatil yerine karar vermelerinde en fazla yararlandıkları üç bilgi kaynağı olarak internet (\% 41), geçmiş deneyimler $(\%$ 15) ve tanıdık tavsiyeleri $(\%$ 9) yararlandıklarını belirtmişlerdir.

Tablo 6'da turistler açısından destinasyon imajını etkileyen faktörlerin dağılımı yer almaktadır. Z Kuşağı katılımcıların tatil yerine karar vermelerinde "Üst Düzey Etkili" olan faktörler sırasıyla destinasyondaki Spor İmkanlarının Varlığı $(4,62)$, Ürün/hizmet Fiyatları $(4,48)$ Bar, Disko ve Kulüplerin Varlığı $(4,40)$, Kültür, Sanat ve Tarihe ilişkin Kaynakların Varlığı (4,39), Destinasyona Seyahatin Moda Olması (4,32), Temalı Parkların Olması ile Lüks Bir Destinasyon Olması $(4,28)$, Ulaşımın Kolay Olması $(4,19)$, Güvenli Oluşu $(4,13)$, Flora ve Faunanın Benzersiz ve Çeşitli Oluşu $(4,08)$, Telekomünikasyon Hizmetlerinin Gelişmişliği $(4,05)$ ile Sahilleri ve Özellikleri $(4,02)$ faktörleridir. Katılımcılar, tatil yerine karar vermelerinde "Alt Düzey Etkili" olan faktörler olarak Ticari Alt Yapının Varlığı $(2,17)$ ve İnşaat Gelişim Boyutu $(2,46)$ faktörlerini belirtmişlerdir.

Kuşağı katılımcıların tatil yerine karar vermelerinde "Üst Düzey Etkili" olan faktörler sırasıyla destinasyondaki Manzara Zenginliği $(4,73)$, Ürün/hizmet Fiyatları $(4,63)$, Kültür, Sanat ve Tarihe ilişkin Kaynakların Varlığı $(4,49)$, Güvenli Oluşu $(4,42)$, Ulaşımın Kolay OIması (4,33), Spor İmkanlarının Varlığı $(4,31)$, Sahilleri ve Özellikleri $(4,23)$, Çevrenin Temizliği ile Restoran Hizmetlerinin Nitelik ve Kalitesi $(4,17)$, Flora ve Faunanın Benzersiz ve Çeşitli Oluşu (4,13), Bar, Disko ve Kulüplerin Varlığı $(4,03)$ ile Destinasyona Seyahatin Moda Olması $(4,01)$ ile faktörleridir. Katılımcılar, tatil yerine karar vermelerinde "Alt Düzey Etkili" olan faktörler olarak Ticari Alt Yapının Varlığı $(2,86)$ ve Telekomünikasyon Hizmetlerinin Gelişmişliği $(2,88)$ faktörlerini belirtmişlerdir.

X Kuşağı katılımcıların tatil yerine karar vermelerinde "Üst Düzey Etkili" olan faktörler sırasıyla destinasyonun Güvenli Oluşu $(4,95)$, Ürün/hizmet Fiyatları ile Hava Koşulları $(4,89)$, Kültür, Sanat ve Tarihe ilişkin Kaynakların Varlığı $(4,80)$, Sağlık Hizmetlerinin Gelişmişliği (4,79), Trafik Durumu (4,65), Ulaşımın Kolay Olması $(4,62)$, Sahilleri ve Özellikleri $(4,43)$, Konaklama Hizmetlerinin Nitelik ve Kalitesi $(4,41)$, Yerel Halkın Davranışları $(4,38)$, Hava ve Gürültü Kirliliği $(4,29)$ ile Aşırı Kalabalıklaşma $(4,23)$ ile faktörleridir. Katılımcılar, tatil yerine karar vermelerinde "Alt Düzey Etkili" olan faktörler olarak Bar, Disko ve Kulüplerin Varlığı $(2,88)$ ve Spor İmkanlarının Varlığı $(2,98)$ faktörlerini belirtmişlerdir. 
Tablo 6: Katılımcılar Açısından Destinasyon İmajını Etkileyen Faktörlerin Dağılımı

\begin{tabular}{|c|c|c|c|c|c|c|}
\hline \multirow{2}{*}{$\begin{array}{l}\text { Destinasyon İmajını Etkileyen } \\
\text { Faktörlere İlişkin Maddeler }\end{array}$} & \multicolumn{2}{|c|}{ Z Kuşağı } & \multicolumn{2}{|c|}{ Y Kuşağı } & \multicolumn{2}{|c|}{ X Kuşağı } \\
\hline & Ortalama* & ss & Ortalama* $^{*}$ & ss & Ortalama* & ss \\
\hline Hava Koşulları & 3,42 & 1,03 & 3,89 & 1,21 & & 1,14 \\
\hline Sahilleri ve Özellikleri & & 0,98 & 10 & 1,16 & 4,43 & 1,10 \\
\hline Manzara Zenginliği & 3,94 & 1,09 & & 1,12 & 3,99 & 1,16 \\
\hline $\begin{array}{l}\text { Flora ve Faunanın Benzersiz ve } \\
\text { Çeşitli Oluşu }\end{array}$ & & 1,01 & 4,13 & 1,10 & 3,83 & 1,18 \\
\hline $\begin{array}{l}\text { Özel ve Kamu Ulaşım Olanaklarının } \\
\text { Varlığı }\end{array}$ & 3,24 & 1,13 & 3,11 & 1,12 & 3,18 & 1,24 \\
\hline $\begin{array}{l}\text { Telekomünikasyon Hizmetlerinin } \\
\text { Gelişmişliği }\end{array}$ & 4,05 & 1,05 & 2,88 & 1,64 & 3,27 & 1,20 \\
\hline Ticari Alt Yapının Varlığı & 2,17 & 1,04 & 2,86 & 1,70 & 3,03 & 1,16 \\
\hline İnşaat Gelişim Boyutu & 2,46 & 1,00 & 3,46 & 1,22 & 3,00 & 1,07 \\
\hline $\begin{array}{l}\text { Konaklama Hizmetlerinin Nitelik ve } \\
\text { Kalitesi }\end{array}$ & 3,50 & 1,07 & 3,73 & 1,04 & 4,41 & 1,12 \\
\hline $\begin{array}{llll}\begin{array}{l}\text { Restoran Hizmetlerinin Nitelik ve } \\
\text { Kalitesi }\end{array} & & \\
\end{array}$ & 3,14 & 1,12 & 4,17 & 1,11 & 3,99 & 1,14 \\
\hline Bar, Disko ve Kulüplerin Varlığı & & 1,05 & 4,00 & 1,26 & 2,88 & 1,10 \\
\hline Ulaşımın Kolay Olması & & 1,04 & 4,33 & 0,98 & 4,62 & 1,20 \\
\hline Turistik Turların Varlığı & 3,89 & 1,11 & 3,52 & 1,00 & 3,04 & 1,18 \\
\hline Turistik Bilgi Ağının Olması & 3,06 & 1,04 & 3,96 & 1,21 & 3,92 & 1,15 \\
\hline Temalı Parkların Olması & & 0,99 & 3,41 & 1,15 & 3,98 & 1,18 \\
\hline Spor İmkanlarının Varlığı & & 1,09 & & 1,07 & 2,98 & 1,10 \\
\hline $\begin{array}{l}\text { Kültür, Sanat ve } \\
\text { Kaynakların Varlığı }\end{array}$ & 4,3 & 0,93 & 4,49 & 0,99 & & 1,09 \\
\hline Sağlık Hizmetlerinin Gelişmişliği & 3,73 & 1,23 & 3,06 & 1,04 & 4, & 1,21 \\
\hline Ekonomik Gelişmişlik & 3,25 & 1,11 & 3,13 & 1,13 & 3,43 & 1,14 \\
\hline Güvenli Oluşu & & 1,15 & & 1,10 & & 1,26 \\
\hline Ürün/hizmet Fiyatları & $4 \Delta 8$ & 1,08 & 4,63 & 1,07 & 4,89 & 1,21 \\
\hline Çevrenin Temizliği & 3,93 & 2,45 & 4,17 & 1,14 & 3,91 & 0,79 \\
\hline Aşırı Kalabalıklaşma & 3,17 & 1,07 & 3,85 & 1,20 & 1,23 & 0,80 \\
\hline Hava ve Gürültü Kirliliği & 3,29 & 1,17 & 3,76 & 1,06 & 4,29 & 0,82 \\
\hline Trafik Durumu & 3,45 & 1,14 & 3,74 & 1,11 & 4,65 & 0,87 \\
\hline Yerel Halkın Da & 3,08 & 1,15 & 3,94 & 1,14 & , & 0,96 \\
\hline Lüks Bir Destinasyon Olması & & 1,20 & 3,87 & 1,28 & 2,88 & 0,89 \\
\hline $\begin{array}{l}\text { Destinasyona Seyahatin Moda } \\
\text { Olması }\end{array}$ & 4,32 & 0,86 & 4,01 & 1,15 & 3,09 & 1,00 \\
\hline Toplam & 3,86 & 0,83 & 4,12 & 0,91 & 4,43 & 0,78 \\
\hline
\end{tabular}

Araştırmaya katılan turistlerin tatil yerine karar vermelerinde destinasyon imajını etkileyen faktörlere ilişkin görüşleri arasında fark olup olmadığını sınamak için, turistlerin kuşaklarına göre oluşturulan grupların görüşlerinin ortalamaları ilişkisiz örneklemler için tek yönlü varyans analizi ile karşılaştırılmış, analiz sonuçları, turistlerin görüşleri arasında $x$, y ve z kuşakları bakımından istatistiksel olarak anlamlı bir fark olduğunu göstermektedir $[F(3-580)=4.72, p=.00]$. Başka bir deyişle, turistlerin, destinasyon imajını etkileyen faktörlere ilişkin görüşleri, kuşaklarına bağlı olarak anlamlı bir şekilde farklılaşmaktadır. Birimler arası farkların hangi gruplar arasında olduğunu bulmak amacıyla yapılan LSD testi sonucunda, anlamlı farkın, "Z Kuşağı" ile "Y Kuşağı" ve "X Kuşağı" arasında olduğu görülmüştür $(p=.00)$. Buna göre, "X Kuşağı" $\left(X_{C}=4.43\right)$ ve " $Y$ Kuşağı" ( $\left.X_{B}=4.12\right)$ turistler, " $Z$ Kuşağı" $\left(X_{A}=3.86\right)$ turistlere göre destinasyon imajını etkileyen faktörlerin daha etkili olduğunu düşünmektedirler. 
Tablo 7: Turistler Destinasyon İmajını Etkileyen Faktörlerin X, Y ve Z Kuşaklarına Göre Karşılaştırılmasına İlişkin Anova Testi Sonuçları

\begin{tabular}{|c|c|c|c|c|c|c|c|c|c|c|}
\hline Boyutlar & Gruplar & $\mathbf{N}$ & $\mathrm{X}$ & $\begin{array}{c}\text { Varyansın } \\
\text { Kaynağı }\end{array}$ & $\begin{array}{l}\text { Kareler } \\
\text { Toplamı }\end{array}$ & Sd & $\begin{array}{c}\text { Kareler } \\
\text { Ortalaması }\end{array}$ & $\mathbf{F}$ & p & $\begin{array}{c}\text { Anlamlı } \\
\text { fark }\end{array}$ \\
\hline \multirow{4}{*}{$\begin{array}{l}\text { Destinasyon } \\
\text { Imajinı } \\
\text { Etkileyen } \\
\text { Faktörlerin }\end{array}$} & A) Z Kuşağı & 200 & 3.86 & Gruplar & 6.564 & 3 & 2188 & \multirow{4}{*}{4.72} & \multirow{4}{*}{$.00^{* *}$} & \multirow{4}{*}{$\begin{array}{l}A-C \\
A-B\end{array}$} \\
\hline & B) Y Kuşağı & 200 & \begin{tabular}{|l|l|}
4.12 \\
\end{tabular} & arası & & 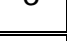 & 2.100 & & & \\
\hline & C) X Kuşağı & 200 & 4.43 & Gruplar içi & 268.977 & 580 & .464 & & & \\
\hline & Toplam & 600 & 3.44 & & 275.541 & 583 & & & & \\
\hline
\end{tabular}

\section{Sonuç ve Öneriler}

İmaj işletmelerin vazgeçilmez değeri olduğu kadar ülkelerinde rekabet avantajı oluşturacak özelliği haline gelmiştir. Bu bağlamda bu niteliklerini geliştiren ve koruyan, yeniden oluşturan ülkeler turizm alanında da öne çıktıkları bilinmektedir. Konuya ülkemiz açısından bakıldığında son dönemlerde bu konularda oldukça olumlu çalışmalar yapılmaktadır. Geleneksel turizm anlayışının dışına çıkılmakta sürdürülebilirlik ön plana taşınmaktadır. Destinasyon konusunda çok avantajlı ve farklı çeşitleri bulunduran ülkemiz, tarihi, kültürü ve coğrafi değerleriyle ile oluşan olumlu imaj sayesinde turizmden aldığı payı giderek arttırmaktadır.

Çalışma örneklemenin belirlenmesinde kota örneklem yöntemi kullanıldığından katılımcılar yaş grupları açısından farklı özellikler göstermekle birlikte erkek sayısının kadın sayısından fazla olduğu, lise mezunlarının ilk sırada yer aldığı ve yarıdan fazlasının (\%56) ayda 3000 TL üzeri gelire sahip olduğu anlaşılmaktadır. Bu duruma etken olarak katılımcıların farklı yaş kuşaklarını temsil ediyor olmaları, dolayısı ile demografik verilerin heterojen bir yapıda olduğu söylenebilir.

Katılımcılar tatile çıkma davranışları açısından incelendiğinde genel olarak dinlenme, eğlenme ve yeni yerler görme nedeniyle tatile çıktıkları saptanmıştır. Bununla birlikte $Z$ ve $Y$ kuşağı katılımcıları en fazla eğlence (sırasıyla \% 32 ve \% 40) nedeniyle tatile çıktıkları, $X$ kuşağı katılımcıların dinlenme $(\% 26)$ ve rahatlama $(\% 19)$ nedeniyle tatile çıktıkları görülmüştür. $Z, Y$ ve $X$ kuşağı katılımcıların tatile çıkma sıklıkları açısından incelendiğinde $Z$ kuşağı katıımcıların yarısına yakını (\% 42), $Y$ kuşağı katılımcıların yarısından fazlası (\% 89) yılda bir kez tatile çıkarken, X kuşağı katılımcıların yarısına yakını (\% 40) yılda üç kez ve daha fazla tatile çıktıkları görülmüştür. Bununla birlikte üç kuşağın da tatil yerine karar vermede en fazla internetten yararlandığı görülmüştür.

Z kuşağı katılımcıların tatil yeri seçiminde etkili olan üç faktör incelendiğinde katılımcılar tatil yeri seçiminde etkili olan en önemli üç faktör olarak eğlence (\% 25), spor olanakları (\% 18) ve tarihi ve kültürel çekicilikler (\%16.5) ve Y kuşağı katılımcıların manzara/doğal çevre (\% 23), eğlence olanakları (\% 18) ve tarihi ve kültürel çekicilikler (\% 15) olduğunu belirtirlerken X kuşağı katılımcıların manzara/doğal çevre (\% 27), destinasyonun imajı $(\% 17)$ ve güvenlik (\% 15) olduğunu belirtikleri görülmüştür. Ziyaretçilerin sosyo-demografik özellikleri algıladıkları imaj üzerinde etkili olmaktadır. Kadınların destinasyonları genel olarak daha olumlu değerlendirdikleri görülmüştür. Yaş bilişsel algılamayı daha çok etkilemekte, yaşlandıkça destinasyonları olumlu algılama olasılığı artmaktadır. Bireylerin bulunduğu kuşak grubu özellikle duygusal algılamalarda etkili olmaktadır (Beerli ve Martin, 2004).

Turistler açısından destinasyon imajını etkileyen faktörlerin dağılımı bakıldığında birçok faktörün etkili olduğu görülmektedir. Kimi faktörler bireyin kendisinden 
kaynaklanmakta iken, kimi faktörler ise destinasyon kaynaklıdır. Gerek algılamaların kişiden kişiye değişiklik gösteriyor olması, gerekse zaman içerisinde aynı kişinin düşüncelerinde meydana gelen değiş̧imler, "imaj" olarak adlandırılan izlenimlerin belirli zaman aralıklarıyla ölçülmesini zorunlu kılmaktadır. Z Kuşağı katılımcıların tatil yerine karar vermelerinde "Üst Düzey Etkili" olan faktörler destinasyondaki Spor İmkanlarının Varlığı $(4,62)$, Y Kuşağı katılımcıların destinasyondaki Manzara Zenginliği $(4,73)$ iken X Kuşağı katılımcıların destinasyonun Güvenli Oluşu $(4,95)$ etkilidir. Bu nedenle turizm destinasyonları için stratejik yönetim kapsamında destinasyon imajı oluşturmak ve geliştirmek pazarlama programlarının uygulanması açısından önem arz eder (Baloglu ve McCleary, 1999: 871).

Olumsuz imaja sahip olan destinasyonun başarılı olma imkanı bulunmamasına rağmen bir destinasyonun başarısında olumlu destinasyon imajı tek başına yeterli olmayacaktır. Bu kapsamda, başarılı olmak isteyen bir destinasyonun belirli aralıklar ile sahip olduğu imajı ölçmesi ve çıkan sonuçlara göre sahip olmak istediği destinasyon imajı ile turistler tarafından algılandığı destinasyon imajı arasındaki açıkları kapatmak için çalışmalıdır. Çünkü bireylerin tercihleri zaman içerisinde değişmektedir. Bu değişimin en önemli belirleyicilerinden biri de bireyin içine bulunduğu kuşak aralığıdır. Turistlerin seyahat davranışlarını anlamak ve etkili pazarlama stratejileri oluşturabilmek için destinasyon imajını doğru ölçebilecek metodolojilerin geliştirilmesi gerekir. Echtner \& Ritchie (2003: 41), fonksiyonel ve psikolojik nitelik taşıması bakımından destinasyon imajının ölçülmesinde kullanılan özellikleri ve bu özelliklerin kullanıldığı araştırmaları inceledikleri çalışma bunu doğrular niteliktedir. Ayrıca bu çalışmada; destinasyona ilişkin içsel ve dışsal faktörlerin yanı sıra turistlerin motivasyonu ve demografik özelliklerinin önemli olduğu vurgulanmıştır.

Destinasyonların fiili ve potansiyel ziyaretçilere hissettirdiği duyguların ve belli başlı özelliklerin ön plana çıkarılması ve şekillendirilmesi konusunda ilgili turizm destinasyonları yöneticilerine ise büyük görevler düşmektedir. $X$ ve $Y$ kuşağı turistler günümüzde halihazırda turizm davranışı içerisinde olmakla birlikte gelecekte de uzunca sayılabilecek bir süre daha potansiyel turist olacaklardır. Bununla birlikte $Y$ kuşağını oluşturan turistler kendilerinden sonra gelen nesil Z kuşağı turistleri de turistik davranışları açından etkileyebilecek bir gruptur. Ayrıca gelecekte potansiyel turist olarak görülen $Z$ kuşağı bireylerin turistik talep tercihlerin $X$ ve $Y$ kuşağı bireylerden farklı olabileceği göz önünde bulundurulmalıdır. Bu nedenle turizm destinasyonlarına ilişkin oluşturulacak destinasyon imajı yaratılmasıyla ilgili olarak bu grubun ( $Z$ kuşağı) özelliklerinin dikkate alınması destinasyonların uzun vadeli olarak fiili ve potansiyel turistler için olumlu imaja sahip olmasına neden olacaktır.

\section{Kaynakça}

Aksoy, R. ve Kiyci, Ş. (2011), 'Destination Image As a Type of Image and Measuring Destination Image in Tourism (Amasra Case)' European Journal of Social Sciences, 20(3), ss. 478-488.

Baloğlu, Ş. (1996), An Emprical Investigation of Determinants of Tourist Destination Image. Yayımlanmamış Doktora Tezi, Virginia Polytechnic Institute and State University.

Baloğlu, Ş. (1997), 'The Relationship Between Destination Images and Sociodemographic and Trip Characteristics of International Travelers' Journal of Vacation Marketing, 3 (3), ss. 221-233.

Baloğlu, Ş. ve Mccleary, W.K. (1999), 'U.S. International Pleasure Travelers' Images of Four Mediterranean Destinations: A comparison of Visitors and Non-Visitors' Journal of Travel and Tourism Research, 8(2), ss. 144-151 
Beerli, A. ve Martin, J. D. (2004), 'Factors Influencing Destination Image' Annals of Tourism Research, 31(3), ss. 657-681.

Büyüköztürk, Ş. (2012), Sosyal Bilimler İçin Veri Analizi El Kitabı, Ankara: Pegem Akademi.

Can, A. (2013), SPSS ile Bilimsel Araştırma Sürecinde Nicel Veri Analizi. Ankara: Pegem Akademi.

Can, B. (2012), http://www.progroup.com.tr/makale_detay.asp?id=59. ( 20.07.2016)

Day, J., Skidmore, S. ve Koller, T. (2002), 'Image Selection in Destination Positioning: A New Approach' Journal of Vacation Marketing, 8(2), ss.177-186.

Echtner, C. M. ve Ritchie, J. R. B. (2003), 'The meaning and Measurement of Destination Image' The Journal of Tourism Studies, 14(1): 37-48.

Gibson, H. J., QI, C. X., ve Zhang, J. J. (2008), 'Destination Image and Intent to Visit China and 2008 Beijing Olympic Games' Journal of Sports Management, 22, ss. 427-450.

İçöz, O. (2001), Turizm İşletmelerinde Pazarlama İlkeleri ve Uygulamalar, Ankara: Turhan Kitabevi Yayınları.

Jafarov, İ. (2003), Azerbaycan'ın Turizm Potansiyelinin Değerlendirilmesi ve Turistik Ürünün Politikası, Yayınlanmamış Yüksek Lisans Tezi, İmir: DEÜ Sosyal Bilimler Enstitüsü, Turizm İşletmeciliği Anabilim Dalı.

Jenkins, O. H. (1999), 'Understanding and Measuring Tourist Destination Images' International Journal of Tourism Research, 1, ss. 1-15.

Kaptan, S. (1998), Bilimsel Araştırma ve İstatistik Teknikleri, Ankara: Tekışık Web Ofset Tesisleri.

Karasar, N. (2009), Bilimsel Araştırma Yöntemi, 20. Baskı, Ankara: Nobel.

Kotler, P., Bowen J. ve Makens, J. (1999), Marketing for Hospitality and Tourism, New Jersey: Prentice Hall.

Kotler, P. ve Armstrong, G. (2004), Principles of Marketing, 10. Baskı, New Jersey: Prentice Hall.

Kozak, M. ve Bahçe S. (2009), Özel İlgi Turizmi, Ankara: Detay Yayıncılık.

Leech, N.L., Barrett, K.C., ve Morgan, G.A. (2005), SPSS for Intermediate Statistics: Use and Interpretation, 2. Baskı, Mahwah, NJ: Lawrence Erlbaum Associates, Inc. Publishers.

Lower, J. (2008), 'Brace Yourself Here Comes Generation Y. Critical Care Nurse' 28(5), 80-84.

Özdamar, K. (2001). Paket Programlar ve İstatistiksel Veri Analizi (Çok Değişkenli Analizler), 4. Baskı, Eskişehir: Kaan Yayınları.

Ryan, C. (2003), Recreational Tourism: Demands and Impacts, Clevedon: Channel View Publications.

Sarma, M.K.(2007), 'Influence of Information Sources on Tourists: A Segment- Wise Analysis with Special Focus on Destination Image' Journal of Business Perspective, 11(1), ss. 35-45.

Şahbaz, R. P. ve Kılıçlar A. (2009), 'Filmlerin ve Televizyon Dizilerinin Destinasyon İmajına Etkileri' İşletme Araştırmaları Dergisi. 1(1), ss. 31-52.

Tavşancıl, E.(2002), Tutumların Ölçülmesi ve SPSS ile Veri Analizi, Ankara: Nobel Yayınevi.

Ural, A. ve Kılıç, I. (2006), Bilimsel Araştırma Süreci ve SPSS ile Veri Analizi, 2.Baskı, Ankara: Detay.

Yıldırım, A. ve Şimşek, H. (2005), Sosyal Bilimlerde Nitel Araştırma Yöntemleri, 5. Baskı, Ankara: Seçkin.

Williams, C. K. ve Page, A. R. (2011), 'Marketing to The Generations' Journal of Behavioral Studies in Business, 3(3)-11. 